BULLETIN OF PNRPU. GEOLOGY. OIL \& GAS ENGINEERING \& MINING

ВЕСТНИК ПНИПУ. ГЕОЛОГИЯ. НЕФТЕГАЗОВОЕ И ГОРНОЕ ДЕЛО

ISSN 2224-9923

Volume/Tom 15 №21 2016

http://vestnik.pstu.ru/geo/

УДК 622.245 .42

Article / Статья

(C) PNRPU / ПНИПУ, 2016

\title{
RESULTS OF TESTING OF LIP PLUGGING DEVICES FOR GEOTECHNICAL WELLS
}

\section{A.A. Makarov}

Kazakh National Research Technical University named after K.I. Satpayev

(22 Satpayev street, Almaty, 050013, Kazakhstan)

\section{РЕЗУЛЬТАТЫ ИСПЫТАНИЙ УСТРОЙСТВА ДЛЯ МАНЖЕТНОГО ТАМПОНИРОВАНИЯ ГЕОТЕХНОЛОГИЧЕСКИХ СКВАЖИН}

\section{А.А. Макаров}

Казахский национальный исследовательский технический университет имени К.И. Сатпаева

(050013, Республика Казахстан, г. Алматы, ул. Сатпаева, 22)

Received / Получена: 12.09.2016. Accepted / Принята: 31.10.2016. Published / Опубликована: 02.12.2016

Keywords:

underground leaching, borehole diameter, gel-cement slurry, the annulus, the drilling fluid, shrink thread, squeezing liquid, borehole wall, discharge hose, drilling, flushing, geophysical studies.
Knowledge of the geological structure of the selected field allows to form a clear idea of the nature (geological and mineralogical composition and physico-chemical properties) of rocks, about the stability of rocks and their propensity to fracture under the influence of geological or technological reasons, etc. All this, in turn, largely determines the possibility of using rational method of drilling for specific conditions of the field. The possibility and feasibility of using drilling method is also determined by the presence of the aquifers. Aquifers play a very important role in choosing fields that are favorable for drilling by used method.

Using of the device simplifies the design and optimize well because of the small drill diameter, reduced quantity of cement slurry and improved quality of cement job. Practically confirmed that the cementing with predetermined regimes there is no slugging, cement slurry evenly fit around columns.

During the construction of technological wells with cementing through the interior of casing with collar device the well value changes significantly. The main factors affecting the change in value of the construction of wells, are timeconsuming to plugging wells, the tripping and the waiting on cement. It was established experimentally that the use of the device for lip plugging a filter column reduces the time required to carry out mentioned types of technological operations.

The calculation of economic efficiency, based on the saving of fixed costs in the implementation of the developed device, showed that the savings in the construction of wells is 177663 tenge while the construction of a geotechnological well with $290 \mathrm{~m}$ depth.

\section{Ключевые слова} подземное выщелачивание, диаметр скважины, гельцементный раствор, затрубное пространство, буровой раствор, стяжная нить, продавочная жидкость, стенки скважины, нагнетательный шланг, разбурка, промывка, геофизические исследования
Знание геологического строения выбранного месторождения позволяет составить ясное представление о характере (геолого-минералогическом составе и физико-химических свойствах) горных пород, слагающих разрез, об устойчивости пород и склонности их к разрушению под действием геологических или технологических причин и т.д. Все это, в свою очередь, во многом определяет возможность использования рационального способа бурения применительно к конкретным условиям выбираемого месторождения. Возможность и целесообразность использования упомянутого способа бурения определяется также и наличием в разрезе водоносных пластов. Пластовые воды играют весьма существенную роль в вопросе выбора месторождений, благоприятных для бурения скважин отработанным способом.

Использование предлагаемого устройства упрощает и оптимизирует конструкцию скважины, так как в этом случае уменьшается диаметр бурения, расход тампонажного раствора и повышается качество работ. Практически подтверждено, что при тампонировании с определенными ранее технологическими режимами отсутствует пробкообразование, т.е. тампонажный раствор равномерно укладывается вокруг колонны.

При сооружении технологических скважин с использованием устройства для манжетного тампонирования фильтровой колонны (УТО) с помощью цементирования через внутреннее пространство обсадной колонны их стоимость изменяется существенно. Основными факторами, влияющими на изменение стоимости сооружения скважин, являются затраты времени на тампонирование скважины, на спускоподъемные операции и на ожидание затвердевания цемента. Экспериментальным путем установлено, что использование устройства для манжетного тампонирования фильтровой колонны сокращает затраты времени на проведение указанных выше видов технологических операций

Проведенный расчет экономической эффективности, основанный на экономии условно-постоянных расходов при внедрении разработанного устройства, показал, что экономия при сооружении скважин составляет 177663 тенге при сооружении одной геотехнологической скважины глубиной 290 м.

Aleksandr A. Makarov - Junior Researcher at the Department of Technology and Technique of Drilling Wells (mob. tel.: +007 7026605561 , e-mail: Makarov_84_@inbox.ru).

Макаров Александр Анатольевич - младший научный сотрудник кафедры технологии и техники бурения скважин (моб. тел.: +007 7026605561 , e-mail: Makarov_84_@inbox.ru). 


\section{Introduction}

There are wide-scale works for construction of hydro-geological and geotechnical wells, which are serving for exploration and extraction of groundwater and solid minerals in the Republic of Kazakhstan. The main method of such wells construction is a rotary drilling with clay drilling mud flushing.

Along with this, well depth is increasing constantly, as well as the number of filds with complicated geological conditions. Generally, it is the reason of being abnormal pressure formation in the well column.

The successful construction of these wells is not possible without a comprehensive improvement of equipment and drilling technology, as well as well casing and productive formation segregation [1].

In order to improve the geotechnical well construction it is necessary to solve complex problems that can be represented by three main blocks: technical, technological, organizational.

The priority task of geotechnical well construction is creating a device for its casing [2]. The differential characteristic of these wells is the use of plastic pipes and relatively small intervals for casing.

Such device should completely exclud the cement slurry ingress in bottomhole formation zone [3], a uniform distribution of cement slurry behind casing, implement casing at low time consumption and expense of cementing materials.

One of these devices which can be used advantageously in the injection well construction is shown in Fig. 1. Casing string 1 with use of adapter 2 connects with filter 3 that detached from latter during casing by clutch 4 . Bush sleeve 10 is fixed by pins 11 inside the casing. Near the lower pipe end 1 there are perforated radial holes that are closed with plugs 8 , which are held by clamping thread 9 against falling. The rubber collar 6 is fixed by the clamp 5 on the adapter 2 .

Such construction of casing string 1 witn adapter 2 equipped with centralizer (not shown on Fig. 1) is lowered into the well and stops in the productive formation interval [4]. For the productive formation isolation from the overlying rocks and water producing formation in the casing string 1 cement slurry is fed, the volume of which depends on the waterproofing interval. Then, wall plugs 12 , on which displacement fluid pressure is operating, is dipped in the casing string 1 [5]. As a result, pressure equal to the sum of hydrostatic and injection pressure effects on the plugs 8 .

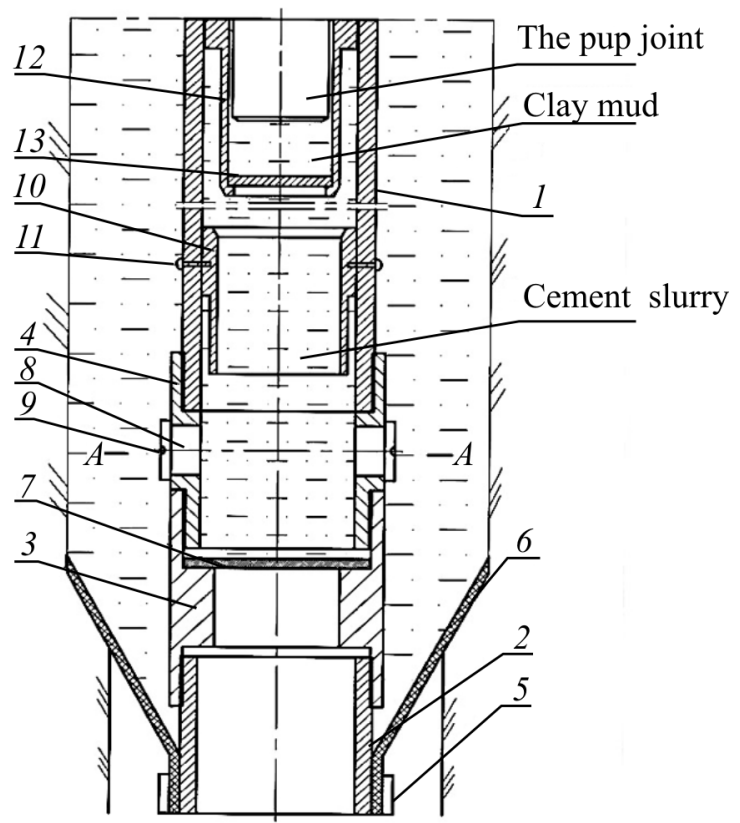

Fig. 1. The device collar casing of injection geotechnical wells (the beginning of casing): 1 - casing string; 2 - adapter; 3 - filter; 4 - clutch; 5 - clamp; 6 - rubber collar; 7 - attenuator; 8 - plugs; 9 - clamping thread; 10 - bush sleeve; 11 - pins; 12 - wall plug; 13 - internal bulkhead

The developed device for collar cementing was tested in landfills underground leaching JSC "Kazatomprom", located in the South Kazakhstan and Kyzylorda regions.

Work areas consist of loose sediments of the Upper Cretaceous, Paleogene, Neogene and Quaternary. Paleozoic basement at a depth of 400$700 \mathrm{~m}$, plunges from north to south and is represented by red Permian sandstones and siltstones. The deposits of the Upper Cretaceous are composed anisomerous sand with gravel and pebbles, which become red-calcareous clays with interbedded calcareous sandstone and siltstone on the top. Cretaceous thickness is $80 \mathrm{~m}$. Paleogene deposits consist of five horizons and one suite, three of which are ore-bearing (kanzhuganskii, Uiukskii, inkanskii horizons). From bottom to top 
well column consists of "motley" horizon deposits that are composed mainly of variegated marl, siltstone with interlayers and lenses of fine-grained sands, which occupy $25-30 \%$ of the total horizon capacity. The total thickness is $20-50 \mathrm{~m}$.

Kanzhuganskii horizon is represented by coastal underwater delta factions. Sand deposits among clays and silts have changeable thickness, which turn in beds and jets sometimes that are productive horizon. Medium and fine-grained, friable sands with argillaceous cement not exceeding 10-15\%. The horizon thickness is $30-60 \mathrm{~m}$.

Kyzylchinskii horizon, that is marking, is represented a layer of green clay with lenses of fine-grained powdery white and greenish sands. The thickness is $0-20 \mathrm{~m}$. The horizon serves confining layer between the productive horizons.

Uiukskii horizon is divided into two packs: the lower mostly consists of sand (productive part) and upper is clay and aleurolitic (upper confining layer). The depth of sand top is $395-524 \mathrm{~m}$. Medium- and fine-grained sands are mostly quartz. The horizon thickness is $20-30 \mathrm{~m}$, the sand thickness is $10-20 \mathrm{~m}$.

In the area Inkanskii horizon tapers off in a northerly direction, the thickness changes from from $15-20 \mathrm{~m}$ to 0 . The horizon is composed of anisomerous sand with carbonaceous detritus. Late Eocene sediments are represented by marine montmorillonite green clay, 40-60 m; Neogene deposits are represented by a layer of redcalcareous clays, which thickness is $30-100 \mathrm{~m}$. Quaternary deposits are composed of alluvial and aeolian sands, which thickness is $30-100 \mathrm{~m}$. All aquifers are sand horizons, with the pressure to self-flowing. Water is fresh.

The wells perform a major role in the technical equipment during the mineral deposits development by underground leaching.

The construction of extraction and injection geotechnical wells is carried by rotational (rotary) method with flushing by mobile rigs DMR$1200 \mathrm{MK}$, that is produced by the engineering support services and complement office of JSC "Volkovgeologiia" [6].

DMR-1200MK has rotary and ZIF-1200MR has spindle rotator, that is the mane difference.
This saves time of pipe extension, which is especially important during drilling soft rock.

The well №34-5-4 being constructed in the West Mynkuduk field, Suzak district, South Kazakhstan region was chosen as a test object.

The rocks are soft and medium drillability (sand, clay, clayey sandstone, siltstone), and the producing formation cosist of anisomerous sand and gravel.

The well constructions are built with $161 \mathrm{~mm}$ drilling bit (drilling interval is $0-290 \mathrm{~m}$ ). $290 \mathrm{~m}$ length casing consist of polyvinylchlorid (PVC 90/8) plastic pipe with a $90 \mathrm{~mm}$ outer diameter and $74 \mathrm{~mm}$ inner diameter. The casing connects with with an $8 \mathrm{~m}$ length plastic PVC filter casing through the collar device. The filter casing is a CDP-118/100 tube with millable slotted holes $3.2 \mathrm{~mm}$ in thickness and $40 \mathrm{~mm}$ in length. A settling basin is installed lower then filter casing, and consists of PVC 90/8 plastic pipe.

Technology of well drilling and construction on NJSC "Kazatomprom" polygons of underground leaching is as follows [7]: $161 \mathrm{~mm}$ diameter three-blade pointed bit is used for drilling the entire depth, mud parameters are: density $\gamma=1.1-1.15 \mathrm{~g} / \mathrm{cm}^{3}$; filtration loss $B=25-30 \mathrm{~cm}^{3} / 30 \mathrm{~min}$ and viscosity $T=18-25 \mathrm{~s}, P \leq 4 \%$.

Drilling is conducted with the axial load $P=700$ $900 \mathrm{daN}$, rotation speed $n=100-200 \mathrm{rev} / \mathrm{min}$ and a flow rate of flushing liquid $Q=200-250 \mathrm{~L} / \mathrm{min}$.

After drilling end of a pilot well directional survey is conducted to determine the deviation from the vertical well axis [8].

Well reaming is produced in stages by $295 \mathrm{~mm}$ diameter tricone bits $\mathrm{M}$ and $\mathrm{C}$ types for drilling to $140 \mathrm{~m}$ depth and $215 \mathrm{~mm}$ diameter tricone bits for drilling to the well bottom (using PNP-110/18 pipes).

The drill-string assembly consists of $73 \mathrm{~mm}$ diameter heavy-weight drill pipe- (or $89 \mathrm{~mm}$ ) with a $12 \mathrm{~m}$ length, $63.5 \mathrm{~mm}$ diameter drill pipe with the transition to $50 \mathrm{~mm}$ diameter steel drillpipe.

PVC 90/8 (or 110/18) casing pipes are installed to the ore horizon roof, after well reaming with appropriate diameter bits [9]. Visual inspection of casing pipes and filters, check the threads using calibres, as well as the check of the internal 
diameter of the pipe with the help of pipe templates is carried out to detect visible defects. All casing threaded connections are sealed with polyisobutylene while making-up. The casing descent is carried out with a weighting $(50 \mathrm{~mm}$ diameter, $200 \mathrm{~m}$ length, $1.200 \mathrm{~kg}$ weight steel drillpipe).

The settling basin of the casing is hermetically sealed with a plug at the bottom. A casing filter surface is covered with the $2 \%$ polyacrylamide film to prevent adhesion of clay during its descent into a well [10].

Cementation of the casing is carried out in two stages:

- setting $10 \mathrm{~m}$ height cement ring, the cement slurry density $\gamma=1.35 \mathrm{~g} / \mathrm{cm}^{3}$;

- cement slurry waterproofing from the roof cement ring to the well mouth, the density $\gamma=1.18-1.25 \mathrm{~g} / \mathrm{cm}^{3}$, the cement concentration is $25 \%$ (250 kg per $1 \mathrm{~m}^{3}$ of mud).

Waiting on cement is conducted for 17 hours after the cementing. Geophysical surveys are made by thermometric method to determine the thickness, quality and interval of a cement ring.

Reaming of ore horizon is done by downhole expander RH 260/320 for installation of gravel pack, the axial load $F=300-400 \mathrm{H}$, rotation speed $n=100-150 \mathrm{rev} / \mathrm{min}$, the flow rate of flushing liquid $Q=200-250 \mathrm{~L} / \mathrm{min}$.

Well stimulation is carried out in two stages for flushing filters achieve the desired flow rate, cleaning the settling basin. The first stage: the well is flushing intervally by technical water and drill pump through the drill bit into the casing, interval standardized, with increasing depth to the settling basin and pure water outlet of the casing, and the beginning of self-flowing. It is 6 hours operation [11].

The second stage: the airlift well stimulation includs the following operations:

- air pipe is deepened on $80 \mathrm{~m}$ below the static level and pumping carried out to full clarification of water with a stops every hour for 10 minutes to measure flow rates (approximately 6 hours);

- air pipe is lowered to a $90-100 \mathrm{~m}$ depth with pumping to full clarification and measurement of flow rates, at a $100 \mathrm{~m}$ depth every 3 hours periodical stops and compressor slopes are held to create fluid hammer with locking at each start reading starting and operating air pressure on manometer, flow rate and the content of suspended solids before stopping;

- the air pipe loading is carried out by 100-110 $\mathrm{m}$ with pumping until clean water to a depth of $200 \mathrm{~m}$.

Further flowmeter is carried out on a filter area to check the filter efficiency.

After the well handing over drilling unit is removed from the site, sumps are pumped and backfilled, the site plan and cleaning of foreign objects is made, stopper closes the casing mouth, the column label with the well number is attached [12].

The offered technology of geotechnological well construction has the following differences from the used previously:

- the final minimum diameter of the well, with is equal to $161 \mathrm{~mm}$ (the exception of the filter set the interval), there is no extension of the well to a $190 \mathrm{~mm}$ diameter; well reaming to $161 \mathrm{~mm}$ diameter is carried out by roller cone bit $\mathrm{M}$ or $\mathrm{C}$ type after drilling with ZL-161 bit with the same diameter [13];

- after the well reaming in 275-285 m producing formation interval to $260 \mathrm{~mm}$ diameter by $260 / 320$ expander mud in the well is replaced by gel-cement slurry with density of $1250 \mathrm{~kg} / \mathrm{cm}^{3}$;

- collar cementing PVC $110 / 18$ casing is carried out (the casing interval is $0-275 \mathrm{~m}$ );

- recommended filter: 63/3.5 PVC pipe, that is set up "countersunk"; gravel package will be implemented through a special device ASB patent RK №17267 [14], reducing the diameter of the gravel frame should not significantly affect the production rate, since the calculation of the rate transverse dimension of gravel package takes into account, rather than the carcass diameter.

\section{The experimental research methodology of device for collar cementing and its results}

Initially, the switchgear variants for the cement slurry supply into the annulus were tested of on the surface. 
The first variant of the device was made in accordance with Fig. 1, it is a tube with radial channels for supplying cement slurry, closed plugs, initially retained by the shrink thread. When the bush sleeve 10 lands on the annular end face of the adapter 2 (see Fig. 1) discharge pressure abruptly increases, and at 2 atm pressure shrink thread (brass wire of $0.4 \mathrm{~mm}$ in thickness) brokes, and plugs are squeezed out of their seats, and mud flows through the radial channels of the device, which has shown its ability to securely perform a required function under test [15-17].

The second variant of the dispenser was also tested in which radial channels are closed by annular rubber valve instead of plugs with shrink thread as in the first variant. Applying pressurized mud annular valve deformed in radial directions missed fluid into the annulus. Expiration plugging fluid speed was regulated by the mud pump pressure. It is found that the deformation of the annular rubber valve in which fluid flow begins in the annulus due to pressure of $2.5 \mathrm{~atm}$ (at $15 \mathrm{~mm}$ thickness of the annular valve). It was also revealed that the consumption of cement slurry in its flow out of the valve is directly proportional to discharge pressure [3].

It should be recognized that the second variant of the switchgear with the annular valve is easier to design concept, however, it requires a lot of calculations, and should be recommended in the future.

Because of the changed requirements of the equipment of a filter casing, it was decided to equip the well carcass filter with slotted holes instead of gravel. This change was due to the fact that the aquifer exploited in this section has been presented with medium sand.

Work on the collar cementing and equipment of the well with filter were conducted as follows [18]:

1. After drilling and flushing the well it is filled with gel-cement slurry.

2. The filter casing of the well are collected on the surface, it consists of the settling basin and a frame-disc filter. Correct assembly of the device for cementing and fastening cuffs reliability is check [19].
3. The frame-disc filter with settle basin is lowered before the switchgear UTO polyvinylchlorid $90 / 8$ and casing. The rubber made of $6 \mathrm{~mm}$ thick acid resistant rubber collar is installed on the casing.

4. After the casing geophysical surveys (GPS) are carried out in order to verify the integrity of the casing and the actual filter installation interval [20].

5. After the GPS first wall packer is dropped in the casing and it is squeezed by cement slurry to seat in the UTO. Then top wall packer is lowered with the bulkhead, with use of which cement slurry is displaced into the annulus. The signal the process end is the increased pressure on the pump pressure gauge at the time of connecting of the top and lower wall packer.

6. After setting of the cement slurry (waiting on cement is 12 hours) temperature survey was carried out for research of cementing quality. The results indicate that the quality of the cementing is quite satisfactory [21].

7. The final stage is the destruction of partitions at the top and lower wall packer for access to the filter part of the well. This operation is carried out by the action of the the lowered drill string weight with the use of which the bulkheads were destroyed, and the drill string freely goes in the filter part of the well [22].

The working time balance of individual collar cementing operations is shown in Table 1.

Table 1

The work time of individual collar cementing operations of the well 35-5-4

\begin{tabular}{|c|l|c|}
\hline $\begin{array}{c}\text { № } \\
\text { o/n }\end{array}$ & \multicolumn{1}{|c|}{ Operation } & $\begin{array}{c}\text { Time for the } \\
\text { operation, hour }\end{array}$ \\
\hline 1 & Landing of the filter casing and the collar & 1.5 \\
\hline 2 & Flushing the well and conducting GPS & 3 \\
\hline 3 & Landing and squeezing of lower packer & 0.5 \\
\hline 4 & $\begin{array}{l}\text { Injection into the casing estimated } \\
\text { volume of cement slurry }\end{array}$ & 0.5 \\
\hline 5 & Landing of top plug & 0.5 \\
\hline 6 & $\begin{array}{l}\text { Squeezing of cement slurry into the } \\
\text { annulus }\end{array}$ & 0.2 \\
\hline
\end{tabular}

Data analysis of the table 1 shows that time required for collar cementing significantly lower then the existing cementing technology through the fill tube disposed in the annulus. 


\section{The calculation of the expected economic effect from the introduction of the developed device for collar cementing of technology wells}

During the construction of technological wells using the device for a collar cementing of the filter casing UTO wells cost of cementing through the casing interior of changes significantly. The main factors affecting on the changes in the well cost of construction [23-25] are the time required for squeezing the well, the time required for tripping and the waiting on cement. It was established experimentally that the use of the device for a collar cementing of the casing filter part [26] reduces time required for carrying out the above-mentioned types of technological operations (see Table 1).

Following the the data in Table 2 and knowing the approximate annual drilling well volume at various sites NJSC "Kazatomprom", it is possible to calculate the expected annual economic efficiency of using the UTO.

Table 2

The time required for well construction

\begin{tabular}{|c|l|c|c|}
\hline \multirow{2}{*}{$\begin{array}{l}|c| \\
\text { № } \\
\text { o/n }\end{array}$} & \multicolumn{2}{|c|}{$\begin{array}{c}500 \mathrm{~m} \text { depth } \\
\text { injection well }\end{array}$} \\
\cline { 3 - 4 } & & $\begin{array}{c}\text { freight } \\
\text { car-hour }\end{array}$ & $\%$ \\
\hline 1 & $\begin{array}{l}\text { The well relative weight in the amount of } \\
\text { the month jobs }\end{array}$ & 101 & 14.5 \\
\hline 2 & Installation, dismantling, design & 4 & 0.6 \\
\hline 3 & well-pilot & 40 & 5.6 \\
\hline 4 & GFS & 5 & 0.7 \\
\hline 5 & 161 mm diameter drilling & 10 & 1.4 \\
\hline 6 & Casing and flushing & 6 & 0.8 \\
\hline 7 & Cementing & 3 & 0.4 \\
\hline 8 & Waiting on cement & 14 & 1.9 \\
\hline 9 & Filter flushing & 8 & 1.1 \\
\hline 10 & GFS after flushing & 8 & 0.4 \\
\hline 11 & Forced-planned works & & \\
\hline
\end{tabular}

With an average well cost (the cost of 1 meter injection well is 10000 tenge, the cost of 1 meter extraction well is 15000 tenge), in our case, the $500 \mathrm{~m}$ depth injection well at the site of Western
Mynkuduk (5000 000 tenge), the cost per hour of drilling unit will be equal to [25]

$$
N=\frac{S}{T}=\frac{5000000}{98,5}=50761 \text { tenge } / \mathrm{h},
$$

where $S$ - the average cost of $500 \mathrm{~m}$ depth well, tenge; $T$ - time spent on the construction of $500 \mathrm{~m}$ depth well at the site of, $h$.

The time required for cementing (Table 3) are reduced by 3.5 hours. Consequently, the economic effect during construction of a well using a collar device for cementing of the casing filter part [27] is 177663 tenge (as using of our device for 1 hour costs 50761 , this value is multiplied by 3.5 is the time spent on cementing using UTO). Considering that on the presented site 500 wells are constructed annually, we have cost savings of 88831750 tenge.

Table 3

The time required for cementing a casing filter, freight car-hour

\begin{tabular}{|l|c|c|}
\hline \multicolumn{1}{|c|}{ Operation } & $\begin{array}{c}\text { Landing of of the drill } \\
\text { string into the annulus }\end{array}$ & $\begin{array}{c}\text { Using the new } \\
\text { technology UTO }\end{array}$ \\
\hline Cementing & 3 & 1.5 \\
\hline $\begin{array}{l}\text { Waiting on } \\
\text { cement with } \\
\text { temperature } \\
\text { survey }\end{array}$ & 14 & 12 \\
\hline
\end{tabular}

\section{Conclusions}

1. Production tests have shown the effectiveness of the developed technical device for well cementing.

2. The use of the device simplifies and optimizes the well design as drilling diameter, consumption of cement slurry are reduced and quality of work increases.

3. Practically confirmed that during cementing with technological modes defined previously there is no slugging, ie cement slurry evenly stacked around the column.

4. The economic efficiency calculation, based on the saving of fixed costs in the developed device implementation, showed that the savings during wells construction of is 177663 tenge in drilling geotechnological well. 


\section{References}

1. Sergienko I.A., Moseev A.F., Bochko E.A. Burenie i oborudovanie geotekhnologicheskikh skvazhin [Drilling and equipment geotechnical wells]. Moscow: Nedra, 1984, 224 p.

2. Makarov A.A., Fedorov B.V. Ustroistvo dlia tamponirovaniia geotekhnologicheskikh skvazhin [Device for geotechnological wells plugging]: innovatsionnyi patent Respubliki Kazakhstan no.21227 2009. Biul. no.4.

3. Sushko S.M., Daurenbekov S.D., Fedorov B.V. Tekhnologiia i tekhnika sooruzheniia geotekhnologicheskikh skvazhin pri podzemnom vyshchelachivanii urana [Technology and technique for geotechnical wells constructions in underground uranium leaching]. Almaty, 2007, $259 \mathrm{p}$.

4. Fedorov B.V., Shemetov D.V. Ustroistvo dlia sozdaniia graviinoi obsypki $\mathrm{v}$ skvazhine [Device for creating a gravel package in well]: predvaritel'nyi patent Respubliki Kazakhstan no.17267. Biulleten' promyshlennoi sobstvennosti, 2006, no.4.

5. Stepin P.A. Soprotivlenie materialov [Strength of materials]. Moscow: Vysshaia shkola, 1988, $367 \mathrm{p}$.

6. Kozlovskii E.A. (Ed.) Spravochnik inzhenera po bureniiu geologorazvedochnykh skvazhin [Engineer's manual for drilling exploration wells]. Moscow: Nedra, 1984, vol. 1, 2.

7. Fedorov B.V. Burenie skvazhin [Drilling of the wells]. Almaty: Izd-vo KazNTU, 2002, 284 p.

8. Leonov E.G., Isaev V.I. Gidroaeromekhanika $\mathrm{v}$ burenii [Drilling hydroaeromechanics]. Moscow: Nedra, 1987, 147 p.

9. Gukasov N.A. Gidrodinamika pri kreplenii [Hydrodynamics when cementing]. Moscow: Nedra, 1979, pp.285-287.

10. Brun V.G., Leonov E.G. Metodika rascheta tsementirovaniia obsadnykh kolonn pri burenii skvazhin [Methodology of calculation cementing casing during drilling]. Moscow: Nedra, 1991, pp.125-130.

11. Gandzhumian R.A., Kalinin A.G. Inzhenernye raschety pri burenii glubokikh skvazhin [Engineering calculations for drilling deep wells]. Moscow: Nedra, 1983, pp.200-215.

12. Birger I.A. Kruglye plastinki i obolochki vrashcheniia [Round plates and shells of revolution]. Moscow: Nedra, 1961, pp.120-145.

13. Klimacheva T.N. AutoCAD dlia studentov (samouchitel') [AutoCAD for students (tutorial)]. Moscow: DMK, 2008, pp.243-247.

14. Shemetov D.V., Fedorov B.V. Ustroistvo dlia graviinoi obsypki fil'tra [Device for gravel package of the filter]: predvaritel'nyi patent Respubliki Kazakhstan no.17267; 2006, biul. no.4, 5 p.

15. Anur'ev V.I. Spravochnik inzhenerakonstruktora [Design Engineer's Manual]. Moscow: Mashgiz, 1980, vol.1.

16. Voalov O.I., Deviatkin O.V. Ekonomika predpriiatiia (firmy) [Economics of enterprise (company)]. Moscow: INFRA-M, 2000, 600 p.

17. Orlov V.P., Daukeev S.Zh. Ekonomika i upravlenie geologorazvedochnym proizvodstvom [Economics and Management Exploration Production]. Moscow-Almaty: Geoinformmark, 1999, 215 p.

18. Abbasov I.B. Sozdaem chertezhi na komp'iutere [Creating drawings on your computer]. Moscow: DMK, 2008, pp.256-300.

19. Arens V.Zh. Geotekhnologicheskie metody dobychi poleznykh iskopaemykh [Geotechnological methods of mineral extraction]. Moscow: Nedra, 1975, $387 \mathrm{p}$.

20. Iazikov V.G., Zabaznov V.L., Petrov N.N., Rogov E.I., Rogov A.E. Geotekhnologiia urana na mestorozhdeniiakh Kazakhstana [Geotechnology in the uranium deposits in Kazakhstan]. Almaty, 2001, $442 \mathrm{p}$.

21. Bulatov A.I. Puti povysheniia kachestva tsementirovaniia skvazhin v Uzbekistane [Ways to improve the quality of cementing in Uzbekistan]. 1976, pp.126-130.

22. Uzhkenov B.S., Akylbekov S.A. Gornometallurgicheskii kompleks Kazakhstana [Mining and metallurgical complex of Kazakhstan]. Trudy mezhdunarodnoi konferentsii "Inzhenernoe obrazovanie i nauka v 21 veke". Almaty: Izd-vo KazNTU, 2004, vol.1, pp.307-318. 
23. Campbell M.D., Lehr J.H. Water well tehnology. New York: McGraw-Hill, 1973, 681 p.

24. Chilingarian G.V., Vorabutr P. Drilling and drilling fluids. Elsevier scientific publishing company. Amsterdam - Oxford - New-York, 1981.

25. Sushko S.M., Begun A.D., Fedorov B.V., Kasenov A.K. Metodika sooruzheniia skvazhin dlia razvedki i dobychi urana metodom PSV [Methods of wells construction for exploration and extraction of uranium by PSV]. Almaty: Iskander, 2007.

26. Fedorov B.V., Makarov A.A., Sushko S.M., Kasenov A.K. Ustroistvo dlia tamponirovaniia geotekhnologicheskikh skvazhin [Device for plugging geotechnological wells]: innovatsionnyi patent Respubliki Kazakhstan no.60191, 15.05.2009, buil. no.5, 5 p.

27. Fedorov B.V., Makarov A.A. Sposob manzhetnogo tamponirovaniia fil'trovoi kolonny geotekhnologicheskikh skvazhin [Method of collar plugging a filter column in geotechnical wells]. Materialy mezhdunarodnoi konferentsii "Resursno-ekologicheskie problemy $v 21$ veke: innovatsionnoe nedropol'zovanie, energetika, ekologicheskaia bezopasnost' $i$ nanotekhnologii". Alushta, 2009.

\section{Список литературы}

1. Сергиенко И.А., Мосеев А.Ф., Бочко Э.А. Бурение и оборудование геотехнологических скважин. - М.: Недра, 1984. - 224 с.

2. Макаров А.А., Федоров Б.В. Устройство для тампонирования геотехнологических скважин: инновационный пат. Республики Казахстан № 21227. 2009. - Бюл. № 4.

3. Сушко С.М., Дауренбеков С.Д., Федоров Б.В. Технология и техника сооружения геотехнологических скважин при подземном выщелачивании урана. - Алматы, 2007. - 259 с.

4. Устройство для создания гравийной обсыпки в скважине: предварительный пат. Республики Казахстан № 17267 / Федоров Б.В., Шеметов Д.В. Бюллетень промышленной собственности. - 2006. - № 4.

5. Степин П.А. Сопротивление материалов. М.: Высшая школа, 1988. - 367 с.

6. Справочник инженера по бурению геологоразведочных скважин / под ред. Е.А. Козловского. - М.: Недра, 1984. - Т. 1, Т. 2.

7. Федоров Б.В. Бурение скважин. Алматы: Изд-во КазНТУ, 2002. - 284 с.

8. Леонов Е.Г., Исаев В.И. Гидроаэромеханика в бурении. - М.: Недра, 1987. - 147 с.

9. Гукасов Н.А. Гидродинамика при креплении. - М.: Недра, 1979. - С. 285-287.

10. Брун В.Г., Леонов Е.Г. Методика расчета цементирования обсадных колонн при бурении скважин. - М.: Недра, 1991. - С. 125-130.
11. Ганджумян Р.А., Калинин А.Г. Инженерные расчеты при бурении глубоких скважин. - М.: Недра, 1983. - С. 200-215.

12. Биргер И.А. Круглые пластинки и оболочки вращения. - М.: Недра, 1961. C. $120-145$.

13. Климачева T.H. AutoCAD для студентов (самоучитель). - М.: ДМК, 2008. - С. 243-247.

14. Шеметов Д.В., Федоров Б.В. Устройство для гравийной обсыпки фильтра: предварительный патент № 17267 Республики Казахстан. - 2006. - Бюл. № 4. - 5 с.

15. Анурьев В.И. Справочник инженераконструктора. - М.: Машгиз, 1980. - Т. 1.

16. Воалов О.И., Девяткин О.В. Экономика предприятия (фирмы). - М.: ИНФАРМА-М, 2000. $-600 \mathrm{c}$.

17. Орлов В.П., Даукеев С.Ж. Экономика и управление геологоразведочным производством. - М.-Алматы: Геоинформмарк, 1999. $215 \mathrm{c}$.

18. Аббасов И.Б. Создаем чертежи на компьютере. - М.: ДМК, 2008. - С. 256-300.

19. Аренс В.Ж. Геотехнологические методы добычи полезных ископаемых. - М.: Недра, 1975. - 387 c.

20. Геотехнология урана на месторождениях Казахстана / В.Г. Язиков, В.Л. Забазнов, Н.Н. Петров, Е.И. Рогов, А.Е. Рогов. - Алматы, 2001. $-442 \mathrm{c}$. 
21. Булатов А.И. Пути повышения качества цементирования скважин в Узбекистане, 1976. - C. 126-130.

22. Ужкенов Б.С., Акылбеков С.А. Горнометал-лургический комплекс Казахстана // Труды международной конференции «Инженерное образование и наука в 21 веке». Алматы: Изд-во КазНТУ, 2004. - Т. 1. C. 307-318.

23. Campbell M.D., Lehr J.H. Water well tehnology. - New York: McGraw-Hill, 1973. $681 \mathrm{p}$.

24. Chilingarian G.V., Vorabutr P. Drilling and drilling fluids / Elsevier scientific publishing company. Amsterdam - Oxford - New-York, 1981.
25. Методика сооружения скважин для разведки и добычи урана методом ПСВ / С.М. Сушко, А.Д. Бегун, Б.В. Федоров, А.К. Касенов. - Алматы: Искандер, 2007.

26. Устройство для тампонирования геотехнологических скважин: инновационный пат. Республики Казахстан № 60191 / Федоров Б.В., Макаров А.А., Сушко С.М., Касенов А.К.; 15.05.2009. - Бюл. № 5. -5 с.

27. Федоров Б.В., Макаров А.А. Способ манжетного тампонирования фильтровой колонны геотехнологических скважин // Материалы международной конференции «Ресурсно-экологические проблемы в 21 веке: инновационное недропользование, энергетика, экологическая безопасность и нанотехнологии». - Алушта, 2009.

Please cite this article in English as:

Makarov A.A. Results of testing of lip plugging devices for geotechnical wells. Bulletin of PNRPU. Geology. Oil \& Gas Engineering \& Mining, 2016, vol.15, no.21, pp.304-312. DOI: 10.15593/2224-9923/2016.21.1

Просьба ссылаться на эту статью в русскоязычных источниках следующим образом:

Макаров А.А. Результаты испытаний устройства для манжетного тампонирования геотехнологических скважин // Вестник Пермского национального исследовательского политехнического университета. Геология. Нефтегазовое и горное дело. 2016. - T.15, №21. - C.304-312. DOI: 10.15593/2224-9923/2016.21.1 